\title{
STATE HEATING OIL AND PROPANE PROGRAM (SHOPP)
}

$$
\begin{aligned}
& \text { FCOI-9UEI } 25059 \\
& \text { DOE/EI/25059-.T/ }
\end{aligned}
$$

1995/96 FINAL REPORT - KENTUCKY

Kentucky's second year of participation in SHOPP was successful. The survey started with a sample group of fifty (50), with forty-nine (49) actually participating. Survey participants were contacted by telephone each reporting period from October to March.

Due to the short time frame for response, the new SHOPP program manager, Margi Jones, sent written correspondence to each participant and contacted them by telephone to introduce herself.

Burna Propane (ID: KY0219) did not participate. They could not be reached by telephone and did not respond to written correspondence. They have an answering service. Several messages were left but no calls were returned. On October 4, 1995 Synergy Gas Corp (ID: KY2341) was inactivated and Empire Energy (ID: KY2348) was added.

In December, Lin-Gas declined to participate for a brief time. Paul Coleman stated that his "boss" had told him he could no longer participate in the survey. The Division of Energy mailed Mr. Coleman a copy of the Public Law 93-275 and a copy of the state operating procedures. After a couple of weeks Margi was told (by EIA via Lin-Gas) to call, leave a message for Joy and she would return the call. We were able to obtain all but the December 18 information and the volume of propane sales for last year.

The division experienceci some problems early on transmitting data, due to moving our offices and again at the end of the survey due to some computer hardware changes. A "call sheet" was faxed to Hans Herzog who offered to enter the data himself.

Some companies reported supply problems, due to allocation, resulting in having to go greater distances to obtain the propane they needed and some reported only being supplied a portion of what they wanted. Most companies did not experience allocation or supply problems. The winter was colder and longer than usual. Wholesale prices did increase. However, most suppliers tried to keep prices down. There were a few reports of problems delivering to customers due to an abnormal amounts of snow in eastern Kentucky.

Kentucky Energy staff thought PEDRO was extremely helpful and easy to utilize. ElA staff, especially Hans Herzog, were courteous and helpful at all times. Kentucky found SHOPP to be an exciting program and we are looking forward to participating next season.

DISTRIBUTON OF THIS DOCUMENT IS UNUATTED
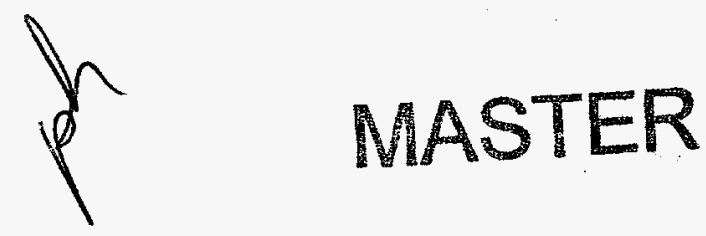


\section{DISCLAIMER}

This report was prepared as an account of work sponsored by an agency of the United States Government. Neither the United States Government nor any agency thereof, nor any of their employees, makes any warranty, express or implied, or assumes any legal liability or responsibility for the accuracy, completeness, or usefulness of any information, apparatus, product, or process disclosed, or represents that its use would not infringe privately owned rights. Reference berein to any specific commercial product, process, or service by trade name, trademark, manufacturer, or otherwise does not necessarily constitute or imply its endorsement, recommendation, or favoring by the United States Government or any agency thereof. The views and opinions of authors expressed herein do not necessarily state or reflect those of the United States Government or any agency thereof. 


\section{DISCLAIMER}

Portions of this document may be illegible electronic image products. Images are produced from the best available original document. 